\title{
The Impact of Interest in Learning on the Use of Time to Study Physics Online
}

\author{
A. Halim ${ }^{1,2 *}$, Yusrizal1, Sri Ayu², Lilia Halim³ \\ ${ }^{1}$ Department of Physics Education, Teacher Training and Education Faculty, Universitas Syiah Kuala, Banda Aceh, Indonesia \\ ${ }^{2}$ Department of Science Education, Graduate School, Universitas Syiah Kuala, Banda Aceh, Indonesia \\ ${ }^{3}$ Departement of Science Education, Fakulti Pendidikan, Universiti Kebangsaan Malaysia, Bangi Seulangor, Malaysia
}

\section{DOI: $10.29303 /$ jppipa.v8i1.830}

\section{Article Info}

Received July 4, 2021

Revised : January 25, 2022

Accepted: January 28, 2022

Published: January 31, 2022

\begin{abstract}
The development of android mobile technology has reduced student interest in learning and this will have an impact on the use of study time. Considering that this phenomenon is important to be studied in more depth, then through this study, it will be investigated the relationship between interest in learning and the use of time. The population of this study were all high school students in the city of Banda Aceh, but due to time and cost constraints, the research respondents were only taken as many as 75 students from 4 high schools in the city of Banda Aceh. Sampling using the proportional sampling method with the consideration that only classes that have implemented subject learning using online media. The data collection instrument used a questionnaire of interest and the use of learning time. Data analysis was carried out in two stages, namely descriptive and inferential analysis. Descriptive analysis was used to obtain the average data, the largest score, and the percentage. While inferential analysis is used to obtain data about the relationship between aspects of interest, aspects of time use with variables of interest and use of time. The results of data analysis showed that the correlation coefficient $\left(r_{-} x y=0.68\right)$ in the high and positive category and the coefficient of determination was $46.24 \%$ at a significant level of 0.05 . Inference from the results of this study, teachers need to attract students' interest in learning by choosing a model or method that has been proven to be reliable, so that students are willing to manage their study time appropriately and efficiently.
\end{abstract}

Keywords: Interests; Utilization of time; Physics learning; Online media

Citation: Halim, A., Yusrizal, Y., \& Halim, L. (2022). The Impact of Interest in Learning on the Use of Time to Study Physics Online. Jurnal Penelitian Pendidikan IPA, 8(1), 408-413. https://doi.org/10.29303/jppipa.v8i1.830

\section{Introduction}

Various forms of expression of the definition of interest in learning have been put forward by educational research experts, including Susanto (2013) who said that interest is an impulse in a person or a factor that raises interest or attention effectively which causes the choice of an object or activity that is profitable, fun and over time will bring satisfaction in him. Another education expert, Slameto (2015) mentions that interest in learning is a form of a person's activity that encourages them to carry out a series of mental and physical activities to obtain a change in behavior as a result of individual experiences in interactions in their environment involving cognitive, affective and psychomotor. Based on the understanding of the experts above, it can be concluded that interest in learning is an impulse in oneself to do something that can make him interested and happy.

Related to interest in learning, there have been many studies conducted, including initial ability and interest in learning affect learning outcomes (Astuti, 2015), learning media and interest in learning affect learning outcomes (Supardi, et al., 2015), self-concept, 
interests and study habits affect learning outcomes. learning outcomes (Hartuti, 2015), and interest in learning affect learning outcomes through the probem based learning model (Wahyuningsih, et al., 2021). Besides interest in learning, it can also be increased through the use of various types of models, methods, techniques, learning media and others. Several previous research results show that physics animation media can increase interest in learning (Sakti, 2013), online learning media can increase students' understanding and interest in learning (Maulidina and Bhakti, 2020), the talking stick learning model can increase interest and learning outcomes (Pasaribu, 2017), and direct learning models through animation media based on macromedia flash can increase interest in learning and understanding concepts (Sakti, et al., 2012).

The second variable in this study is study time. Learning time is defined as an opportunity available in order to gain knowledge, skills, habits, intelligence, and attitudes on a regular basis and to obtain a new overall change in behavior (Purwanto, 2006). Several previous research results show that learning time and interest affect learning outcomes (Lestari, 2015), learning time management affects mathematics learning achievement (Juliasari and Kusmanto, 2016), and motivation and study time affect accounting learning achievement (Devi, 2018).

Based on the results of observations that have been made at several secondary schools in the city of Banda Aceh, it shows that students still use smartphones for personal purposes such as playing games during study hours. Besides that, students only do the assignments given by the teacher, after that students use their smartphones for things that are not related to learning. Utilization of time that should be used to learn and understand the material, is misused for things that are not related to learning. This shows that students are still less interested in participating in the online teaching and learning process.

Based on the results of previous studies as well as the results of observations at the school where the study was conducted, it was shown that asking to study the sciences (physics, biology and chemistry) would be affected by the use of study time. In addition, it was also found that students who have a high interest in playing games with Android will reduce the use of time for learning. Aspects of interest measured in this study are happy without coercion, active in learning activities, participating in forums, focusing and involvement. Meanwhile, aspects of the use of study time include regular study, discipline and enthusiasm, concentration and preparation of study time. Therefore, through this study, it is important to know (a) which aspects of interest in learning are significantly related to the use of study time (Q1), (b) Overall, how is the relationship between interest in learning and use of study time (Q2), and (c) What is the form of the TAM model for the correlation between aspects of learning interest and the use of study time? (Q3).

\section{Method}

\section{Types of Research}

The research approach chosen in this study is a quantitative research approach with survey methods and correlational design. Based on this design, this study aims to determine the effect of the independent variable, namely interest in learning on the dependent variable, namely the use of study time.

\section{Population and Sample of Research}

The population in this study were all students in 16 senior high schools in Banda Aceh. Meanwhile, the sample schools selected using the cluster sampling technique were State Senior High Schools no.1, no.2, no.5, and no.12. Furthermore, respondents were selected using a proposive sampling technique, namely respondents who used online learning and such respondents were in class XI in 4 schools as many as 75 students.

\section{Instruments of Research}

The type of instrument used is adjusted to the research objectives and the variables studied are interest in learning and use of study time. The results of both measurements are in the form of ordinal data, so the instrument that is suitable for use is a questionnaire using a 4-point Likert scale, namely Always (Al), Often $(\mathrm{Ot})$, Rarely $(\mathrm{Rr})$ and Never $(\mathrm{Nv})$. The scoring norms for the interest questionnaire and the use of learning time are in table 1.

Table 1. Scoring Norms of Interest Questionnaire and Study Time Utilization

\begin{tabular}{lll}
\hline $\begin{array}{l}\text { Answers } \\
\text { Alternative }\end{array}$ & $\begin{array}{l}\text { Score Favourable } \\
(+)\end{array}$ & $\begin{array}{l}\text { Score Unfavourable } \\
(-)\end{array}$ \\
\hline Always & 4 & 1 \\
Often & 3 & 2 \\
Rarely & 2 & 3 \\
Never & 1 & 4 \\
\hline
\end{tabular}

(Sugiyono, 2016)

The outline of interest and time utilization questionnaires are shown in table 2 and table 3.

\section{Data Collecting}

In accordance with the survey research design, which uses a correlation technique or without treatment, the data is collected after the learning process using online media and is carried out only once. The first is 
collecting data on student interest in learning with online media and the following stage is collecting data on the use of learning time during learning with online media.

Table 2. The outlines of learning interest instruments

\begin{tabular}{llll}
\hline Variables & Indicators & No.items & Sum \\
\hline $\begin{array}{l}\text { Interest of } \\
\text { Learning }\end{array}$ & $\begin{array}{l}\text { Happy without } \\
\text { coercion } \\
\text { Active in } \\
\text { learning } \\
\text { activities }\end{array}$ & $1,2,3$ & 3 \\
& $\begin{array}{l}\text { Participate in } \\
\text { the forum }\end{array}$ & $7,8,9$ & 3 \\
& $\begin{array}{l}\text { Focusing } \\
\text { Involvement }\end{array}$ & $10,11,12$ & 3 \\
Sum & $13,14,15$ & 3 \\
\hline
\end{tabular}

(Andry, 2018)

Table 3. The outline of Time Utilization Instrument

\begin{tabular}{llll}
\hline Variable & Indicators & No.item & Sum \\
\hline Learning & Study regularly & $1,2,3,4$ & 4 \\
Time & Discipline and & $5,6,7$ & 3 \\
& $\begin{array}{l}\text { passion } \\
\text { Concentration }\end{array}$ & $8,9,10,11$ & 4 \\
& $\begin{array}{l}\text { Study time } \\
\text { allotment }\end{array}$ & $12,13,14,15$ & 4 \\
Sum & & & 15
\end{tabular}

(Maya, 2017)

\section{Data Analysis}

After all the necessary data has been collected, the next step is to analyze the data to obtain information in accordance with the research objectives. Data analysis is divided into two stages, namely the initial stage of data analysis using descriptive statistics to obtain data on average, percentage, score of each item or total score for variables of interest in learning and use of study time. The next stage is to use inferential statistics to obtain information about the relationship between aspects of learning interest and aspects of the use of study time.

\section{Results and Discussion}

\section{The Relationship between the Aspects of Varaibles}

Based on the results of data analysis from interest questionnaires and learning time utilization questionnaires, several findings were obtained, including those shown in Figure 1.

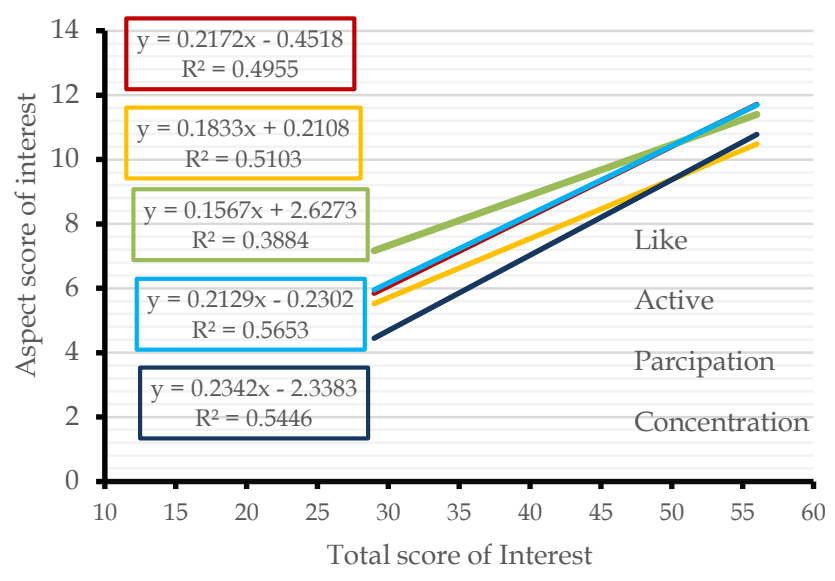

Figure 1. The relationship between the score of the aspect of interest and the total

The graph in Figure 1 provides information on the relationship between aspects of interest in learning and the total score of the variable of student interest in learning by using online media. The involvement of students in groups through online learning significantly affects the total score of the variable interest in learning. In other words, about $54 \%$ of the variable scores of interest in learning were contributed by the aspect of student involvement in the group. While the lowest contribution is from the aspect of student participation in discussion forums, which is around 38,9\%.

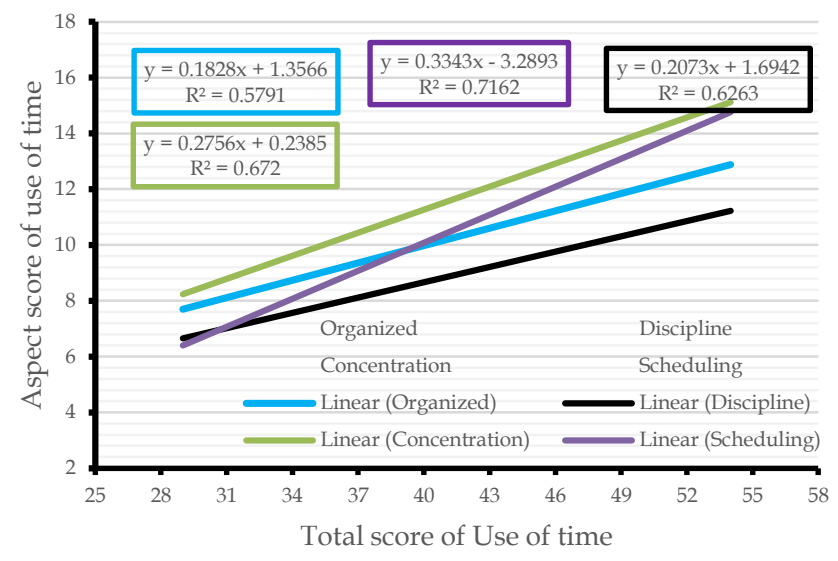

Figure 2. The relationship between the time aspect score and the total

The graphic data in Figure 2 explains the relationship between aspects of time use and the total score of the time use variable in online learning. Based on the graph, it can be understood that the discipline of time use for learning is significantly affected or contributes $71.6 \%$ to the total score of the measurement of the time use variable. The lowest aspect of the use of study time is the aspect of time management with a contribution of $57.9 \%$ to the total score of the time use variable. Based on the graphs in Figure 1 and Figure 2, it can be understood that the overall score contribution of 
the aspects of the use of time to the total score of the variable of time use is higher than the contribution of the aspects of asking to learn to the total score of the variable of interest in learning.

\section{Aspects of Interest in Learning and Use of Time (Q1EQ2)}

The first objective of this study is to obtain information on the relationship between aspects of student interest in online learning (Q1 \& Q2).

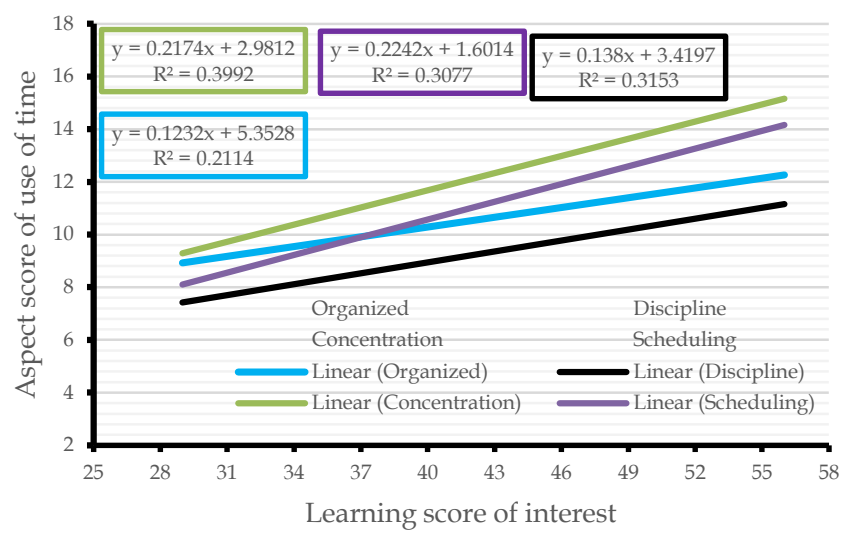

Figure 3. The relationship between scores of aspects of the use of time with a learning interest score

Based on the graph in Figure 3 shows that the influence of interest in learning online on setting learning time is the most dominant in the aspect of time focus or aspects of using time appropriately with a contribution of around $39.92 \%$. While the influence of interest in learning on the aspect of the use of time the lowest is the aspect of setting the use of time with a distribution of about $21.14 \%$. However, the overall effect of interest in learning on the use of online learning time is in the medium and positive category with a slope of 0.703, as shown in Figure 4 .

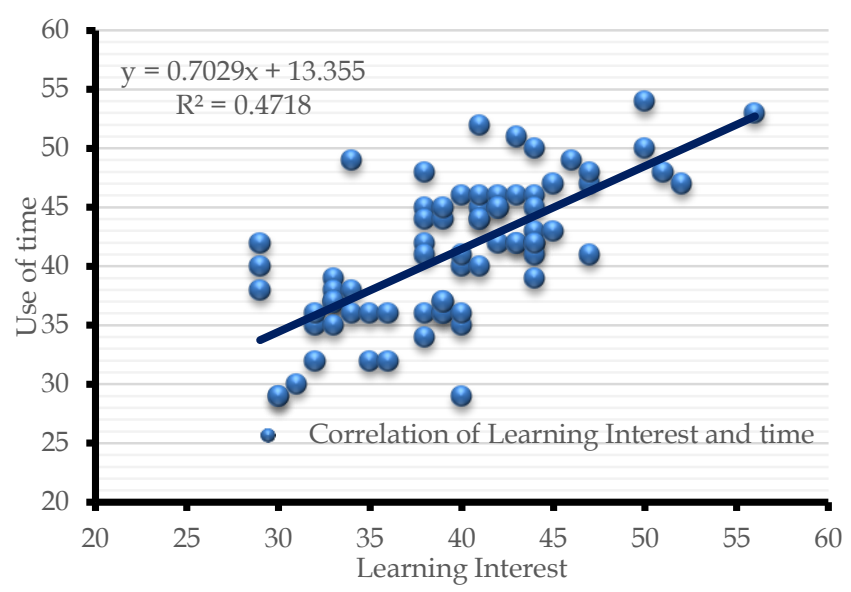

Figure 4. Correlation of Learning Interest and use of time

Furthermore, based on Figure 4, it can also be understood that online learning interest affects learning time management with a contribution of around $47.18 \%$ with a correlation coefficient (r_xy) of around 0.687, meaning that both variables have a high and positive correlation.

\section{TAM Model Correlation between Aspects (Q3)}

The final objective of this study is to obtain the relationship between aspects of the variables of interest in learning and use of study time. The results of data analysis are shown in the TAM model diagram in Figure 5 (Rafique et al, 2020).

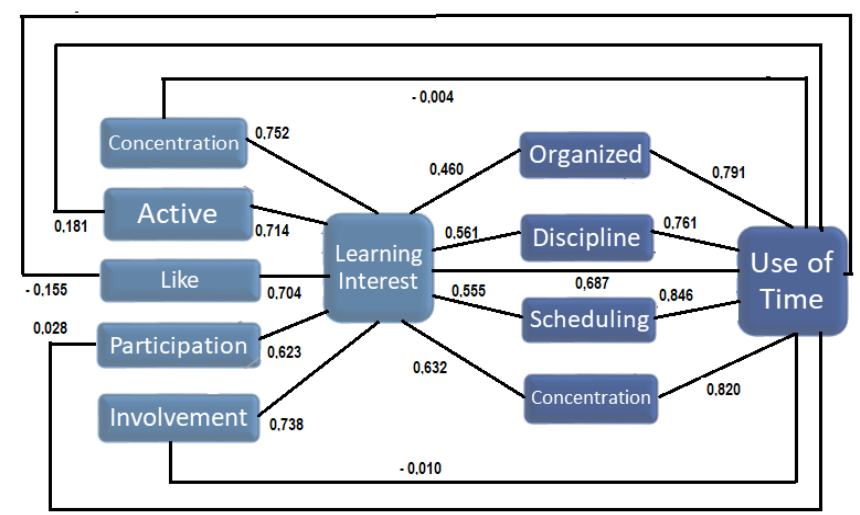

Figure 5. Correlation between aspects of the TAM model

The TAM model in Figure 5 is usually used in the world of technology acceptance research and explains the relationship between aspects of technology acceptance. The same model is also used in this study to explain the relationship between aspects that exist in the variable of interest in learning and the variable of time use.

The information in Figure 5 can be understood that on average the highest correlation between aspects is the correlation between aspects of interest and the total score of the variable interest in learning (0.706), as well as the correlation between aspects of the use of time and the total score of the variable of time use (0.805). Based on the diagram, it was also found that interest in learning online had a very significant effect $(0.846)$ on student scheduling. In other words, students who have a very high interest in learning will encourage students to manage their study time well. However, there are some relationships that occur in reverse or negative correlations, including the relationship between the aspect of interest in learning "happy" with the variable use of study time (-0.155) and the aspect of interest in learning "concentration" with the variable use of time (0.004). In other words, students who are highly interested in online learning tend to be not good at managing study times.

Besides the impact of interest in learning on learning time management, interest in learning also affects several other variables, including the impact of interest in learning on learning to visit the Aquarium 
(Falk, and Adelman, 2003), on attitudes and learning outcomes (Walkington, 2013), and the impact on learning outcomes. the ability to read and write expository (Hidi and Anderson, 1992). On the other hand, interest in learning can also be increased by using various forms of models, methods or techniques, including using interactive multimedia (Primamukti and Farozin, 2018), using comics (Aini et al, 2017), using an inquiry learning model (Sormin et al, 2019), using Blog-based visual learning media (Mutia et al, 2020), using Handbooks on the concept of reaction rate (Handayani et al, 2021), using internet media (Nuraisyah et al, 2021), using an inquiry learning model (Rosnidar et al, 2021), using Smartphones (Suwa et al, 2020), using PBL (Maidan et al, 2020), and audio-visual-assisted discovery learning models (Afrrannisah et al, 2021). While the timing of study can affect several other variables, including the use of local study time affects student achievement, behavior and attitudes (Sanford and Evertson, 1983), and the use of student study time differs between countries (Rees, 2017).

\section{Conclussion}

Based on the results of data analysis, it can be concluded that there is a positive and significant influence between learning interest on the use of online physics learning time by high school students in the city of Banda Aceh. The aspect of the interest in learning variable that has the most significant influence on the tital score of the variable interest in learning is the aspect of concentration, while the lowest significant is participation in the learning process. While the aspect of the use of time in online learning the most significant influence is the aspect of scheduling study time and the least significant is the aspect of discipline in the use of time. Overall, all aspects of learning interest are very low in correlation with the use of study time.

\section{Acknowledgement}

We thank all the staff of the physics education study program and the science education master's program at Syiah Kuala University who have assisted in the research and writing of this article. We also thank all the teaching staff at the Banda Aceh City Senior High School who have assisted in this study activity.

\section{References}

Afrrannisah, A., Yusrizal, Y., \& Nur, S. (2021). Implementation of Audio Visual Assistant Guided Discovery Learning Model to Improve Student's Interest in Learning and Concepts Understanding. Jurnal Penelitian Pendidikan IPA, 7(Speciallssue),
297-304.

https://doi.org/10.29303/jppipa.v7iSpecialIssue.1 164.

Arini, F. D., Choiri, A. S., \& Sunardi, S. (2017). The Use of Comic As A Learning Aid To Improve Learning Interest of Slow Learner Student. European Journal of Special Education Research, 2(1), 71-78. http://dx.doi.org/10.46827/ejse.v0i0.415

Astuti, S. P. (2015). Pengaruh kemampuan awal dan minat belajar terhadap prestasi belajar fisika. Formatif: Jurnal Ilmiah Pendidikan MIPA, 5(1). http://dx.doi.org/10.30998/formatif.v5i1.167

Devi, A. P. C. (2018). Pengaruh motivasi belajar dan pemanfaatan waktu belajar siswa di luar jam pelajaran terhadap prestasi belajar akuntansi. Jurnal Pendidikan Akuntansi Indonesia, 16(1), 23-34. https://doi.org/10.21831/jpai.v16i1.20165

Falk, J. H., \& Adelman, L. M. (2003). Investigating the impact of prior knowledge and interest on aquarium visitor learning. Journal of research in science teaching, 40(2), 163-176. https://doi.org/10.1002/tea.10070

Handayani, Z., Halim, A., \& Khaldun, I. (2021). The Impact of Handbooks on the Concept Understanding and Learning Interests of Students on the Concept of Reaction Rate. Jurnal Penelitian Pendidikan IPA, 7(2), 239-248. https://doi.org/10.29303/jppipa.v7i2.628

Hartuti, P. M. (2015). Peran konsep diri, minat dan kebiasaan belajar peserta didik terhadap prestasi belajar fisika. Formatif: Jurnal Ilmiah Pendidikan MIPA, $5(2)$. http://dx.doi.org/10.30998/formatif.v5i2.329

Hidi, S., \& Anderson, V. (1992). Situational interest and its impact on reading and expository writing. The role of interest in learning and development, 11, 213214. Retrieved from https://psycnet.apa.org/record/1992-97926-009

Juliasari, N., \& Kusmanto, B. (2016). Hubungan Antara Manajemen Waktu Belajar, Motivasi Belajar, Dan Fasilitas Belajar Dengan Prestasi Belajar Matematika Siswa SMP Kelas VIII Sekecamatan Danurejan Yogyakarta. Jurnal: UNION, 4(3), 405412. https://doi.org/10.30738/.v4i3.435

Lestari, I. (2015). Pengaruh waktu belajar dan minat belajar terhadap hasil belajar matematika. Formatif: Jurnal Ilmiah Pendidikan MIPA, 3(2). http://dx.doi.org/10.30998/formatif.v3i2.118

Maulidina, S., \& Bhakti, Y. B. (2020). Pengaruh media pembelajaran online dalam pemahaman dan minat belajar siswa pada konsep pelajaran fisika. ORBITA: Jurnal Kajian, Inovasi Dan Aplikasi Pendidikan Fisika, 6(2), 248-251. https://doi.org/10.31764/orbita.v6i2.2592 
Mutia, L., Gimin, G., \& Mahdum, M. (2020). Development of Blog-Based Audio Visual Learning Media to Improve Student Learning Interests in Money and Banking Topic. Journal of Educational Sciences, $4(2)$, 436-448. http://dx.doi.org/10.31258/jes.4.2.p.436-448

Nuraisyah, S., Harahap, R. D., \& Harahap, D. A. (2021). Analysis of Internet Media Use of Student Biology Learning Interest During COVID-19. Jurnal Penelitian Pendidikan IPA, 7(2), 213-217. https://doi.org/10.29303/ippipa.v7i2.624

Pasaribu, D. S., Hendri, M., \& Susanti, N. (2017). Upaya meningkatkan minat dan hasil belajar fisika siswa dengan menggunakan model pembelajaran talking stick pada materi listrik dinamis di kelas X SMAN 10 Muaro Jambi. Edufisika: Jurnal Pendidikan Fisika, 2(01),

61-69. https://doi.org/10.22437/edufisika.v2i01.4043

Primamukti, A. D., \& Farozin, M. (2018). Utilization of interactive multimedia to improve learning interest and learning achievement of child. Jurnal Prima Edukasia, 6(2), 111-117. http://dx.doi.org/10.21831/jpe.v6i2.19183

Purwanto, N. (2006). Psikologi Pendidikan. Bandung: PT Remaja Rosdakarya.

Rafique, H., Almagrabi, A. O., Shamim, A., Anwar, F., \& Bashir, A. K. (2020). Investigating the acceptance of mobile library applications with an extended technology acceptance model (TAM). Computers $\mathcal{E}$ Education, 145 , 103732. https://doi.org/10.1016/j.compedu.2019.103732

Rosnidar, R., Yusrizal, Y., Mustafa, M., \& Susanna, S. (2021). Application of Discovery Learning Model in Increasing Student Interest and Learning Outcomes. Jurnal Penelitian Pendidikan IPA, 7(4), 542-548. https://doi.org/10.29303/ippipa.v7i4.745

Sakti, I. (2013). Pengaruh media animasi fisika dalam model pembelajaran langsung (direct instruction) terhadap minat belajar dan pemahaman konsep fisika siswa di SMA Negeri Kota Bengkulu. Prosiding SEMIRATA 2013, 1(1). Retrieved from https://jurnal.fmipa.unila.ac.id/semirata/article/ view $/ 778$

Sakti, I., Yuniar Mega, P., \& Risdianto, E. (2012). Pengaruh model pembelajaran langsung (Direct Instruction) melalui media animasi berbasis macromedia flash terhadap minat belajar dan pemahaman konsep fisika siswa di SMA Plus Negeri 7 Kota Bengkulu. Exacta, 10(1), 1-10. Retrieved from http:/ / repository.unib.ac.id/6693/

Slameto. (2003). Belajar dan Faktorfaktor yang Mempengaruhinya. Jakarta: PT. Rineka Cipta.

Sormin, E., Julianti, K., Nadeak, B., \& Naibaho, L. (2019). Use of construction inquiri learning model to improve the interest of learning students grade XI
SMA Angkasa 2 in coloid materials. PEOPLE International Journal of Social Sciences, 5(2), 908-917. http://dx.doi.org/10.20319/pijss.2019.52.908917

Sugiyono. (2016). Metode penelitian kuantitatif, kualitatif dan RED. Bandung: Alfabeta.

Sugiyono. (2017). Metode penelitian pendidikan (pendekatan kuantitatif, kualitatif dan RED). Bandung: Alfabeta.

Supardi, S. U., Leonard, L., Suhendri, H., \& Rismurdiyati, R. (2015). Pengaruh media pembelajaran dan minat belajar terhadap hasil belajar fisika. Formatif: Jurnal Ilmiah Pendidikan $M I P A$, http://dx.doi.org/10.30998/formatif.v2i1.86

Susanto, A. (2013). Teori Belajar dan Pembelajaran di Sekolah Dasar. Jakarta: Kencana Prenada Media Group.

Wahyuningsih, E. T., Purwanto, A., \& Medriati, R. (2021). Hubungan Minat Belajar dengan Hasil Belajar Fisika Melalui Model Project Based Learning Di Kelas XI MIPA SMAN 6 Kota Bengkulu. Jurnal Kumparan Fisika, 4(2), 77-84. https://doi.org/10.33369/jkf.4.2.77-84

Walkington, C. A. (2013). Using adaptive learning technologies to personalize instruction to student interests: The impact of relevant contexts on performance and learning outcomes. Journal of Educational Psychology, 105(4), 932. http://dx.doi.org/10.1037/a0031882

Suwa, A. M., Halim, A., \& Zainuddin. (2020). The Influence of Using Smartphone to Interesting Learning and GPA in Students at Physics Education Department. Asian Journal of Science Education, 2(1), 18-23. https://doi.org/10.24815/ajse.v2i1.14734

Maidan, Halim, A., Safitri, R., \& Nurfadilla, E. (2020). Impact of Problem-based Learning (PBL) model through Science Technology Society (STS) approach on students' interest. Journal of Physics: Conference Series, 1460(012145), 1-7. https://doi.org/10.1088/17426596/1460/1/012145

Sanford, J. P., \& Evertson, C. M. (1983). Time use and activities junior high classes. The Journal of Educational Research, 76(3), 140-147.

Rees, G. (2017). Children's activities and time use: Variations between and within 16 countries. Children and Youth Services Review, 80, 78-87. https://doi.org/10.1016/j.childyouth.2017.06.057 